\title{
THE STUDENTS PERSPECTIVE ON USING AN E-LEARNING PLATFORM: E-OWL
}

\author{
Isabel Araújo ${ }^{1,2}$ and Pedro Miguel Faria ${ }^{1}$ \\ ${ }^{I}$ Instituto Politécnico de Viana do Castelo, Viana do Castelo, Portugal \\ ${ }^{2}$ Centre for Studies in Education and Innovation (CI\&DEI), Instituto Politécnico de Viseu, Portugal
}

\begin{abstract}
The evolution of ICT and its adoption in higher education is driving greater interactivity in teaching and learning processes. The teaching/learning paradigm has been changing. Both educational actors, teacher and student, are increasingly adapting to use technologies. This article presents a study that enhances how technologies can be used in the teaching and learning process, through a mathematics content platform, for higher education students. A survey of the state of the art was made in order to demonstrate some advantages of the teaching-learning process, the teacher's and student's behavior' profiles and their role in relation to the use of new technologies. The main objective of this study is to analyze the student's view on the use of the E-OWL platform in the learning process, and thus contribute to the development of more interactive and motivating learning environments. The privileged instrument in this study was the questionnaire, applied after the use of the platform in an educational context, to students of the Computer Graphics and Multimedia Engineering degree. The results obtained revealed that students demonstrate ease in using the E-OWL platform and that was useful in supporting the course, stimulating continuous study and allowing self-regulation of learning, confirming the relevance of an increasing adoption of ICT in an e-learning context.
\end{abstract}

\section{KEYWORDS}

E-learning, ICT, LMS, Virtual Learning Environments, Higher Education, Engineering Teaching

\section{INTRODUCTION}

Developments in technology allow a faster access to a greater number of people, which drives changes in a number of areas, including the higher education concerning its educational context. The use of information and communication technologies (ICT) in the educational context is a reality in higher education, boosting interactivity in the learning process (Daniela, Strods, \& Daiga, 2019; Kirkwood \& Price, 2014). However, the teaching-learning process in higher education Institutions sometimes cannot keep pace with technological changes. The current students, born of the digital generation, have a greater ability with the new technologies, while part of the teachers still reluctant to use ICTs (Lobo \& Maia, 2015). According to Moran (2007) technologies are important in an educational context, but they don't solve the fundamental issues because "if teaching only depended on technologies, we would have found the best solutions a long time ago" (Moran, 2007:12). In this sense, several studies have been carried out (Nortvig, Petersen \& Balle, 2018) highlighting the relevance of using ICTs, both at the students' level (Paechter, Maier \& Macher, 2010; Al-Rahmi et al 2018) and at the teachers' level (Al-Samarraie, 2018). According to Ricoy and Couto (2014) the use of good pedagogical practices through the use of ICT is an innovative situation, related to the integration of strategies involving dynamism and interactivity that allow significant learning with high educational value. Moreover, it enhances good academic results when associated with the satisfaction of students and teachers.

This article presents how technologies can be used in the teaching learning process, through the usage of a Web platform with mathematical content, focused in higher education students. The objective of this article is to describe a first study on using the E-OWL platform in an educational context, highlighting the student's point of view on using it in their learning processes. The article is organized in six sections starting by the introduction, followed by a context of using technologies in the teaching-learning process in higher education, then a brief introduction the -E-OWL platform is made, the method used in this study is described and a section focused in the analysis of results is detailed before the conclusions. 


\section{ICT IN HIGHER EDUCATION IN AN EDUCATIONAL CONTEXT}

The influence of ICT in education has contributed to the evolution of conventional classes, essentially based on the expositive method, which are being overcome. The teacher, who holds the knowledge and the student who is the receiver, i.e. the concept of the teacher transmitting the knowledge and the student memorizing it to carry out the assessment tests is evolving to a context in which the teacher acts as a supervisor, i.e. being a knowledge facilitator and the student constructs his own knowledge, in a more active and critical way. It should be noted that conventional teaching methods do not appeal to students.

In order to arouse interest and attention it is necessary to be attentive to their daily lives and, furthermore, integrated with technological changes (Antunes, 2010). The expansion of professional performance, mainly the HEI teachers, is related to a continuous pedagogical improvement, carrying out a reflection on their theoretical and practical knowledge, observing difficulties and needs for the qualification of teaching, seeking a teaching that is more participatory, meaningful and innovative (Carabetta Júnior, 2010). However, the use of the Internet, or the computer, for example, is no guarantee that a student will build knowledge. It is up to the teacher to know how to explore the educational potential offered by these resources and to create situations so that the student can mean and understand the information obtained, generating new knowledge Valente (2002, 2003).

Information and communication technologies (ICTs) present new possibilities for the individual to experience creative processes, establishing unexpected approximations and associations, bringing together previously disconnected meanings and expanding the capacity of interlocution through the different languages that such resources provide (Martinsi, 2008). In this sense, seeking new methodological strategies, involving ICT, which are part of students' daily lives, from a very early age, is essential for professionals in the educational field. Thus, it is fundamental to know the methodological possibilities that technologies bring to work the content, through creative activities, a process of conscious and reflective development, using pedagogically the technological resources, with a perspective of transforming school learning (Pereira \& Freitas, 2010).

The use of technology alone does not represent pedagogical change, if it is used only as technological support to illustrate the classes. What becomes necessary is that it be used as a learning mediation so that there is an improvement in the teaching learning process. The simple access to technology itself is not the most important aspect, but the creation of new learning environments and new social dynamics from the use of these new tools (Moraes \& Varela, 2007). For Moran (2007) technologies have not replaced teachers but will enable various tasks and functions of teachers to be transformed. Freire and Shor (1986) state that the task of passing information can be left to databases, books, videos or programs (...) In this way, it is possible for the teacher to become a stimulator of student learning, arousing in them the curiosity to know, to research, and to seek the most relevant information.

Thus, the new higher education teacher, facing ICTs, must have content knowledge, teaching methodology, know how to deal with emotions, be committed to the production of knowledge through research and extension and, above all, break the paradigms of conservative ways of teaching, learning, researching and evaluating with technological innovations (Bertoncello, 2010).

\section{THE E-OWL PLATFORM}

Several online platforms to support higher education have been developed in the last two decades, namely in the area of Mathematics, such as Imathematics, MathYou, GCSE Maths, PMate, M@t-Educate-with-success, among others. 


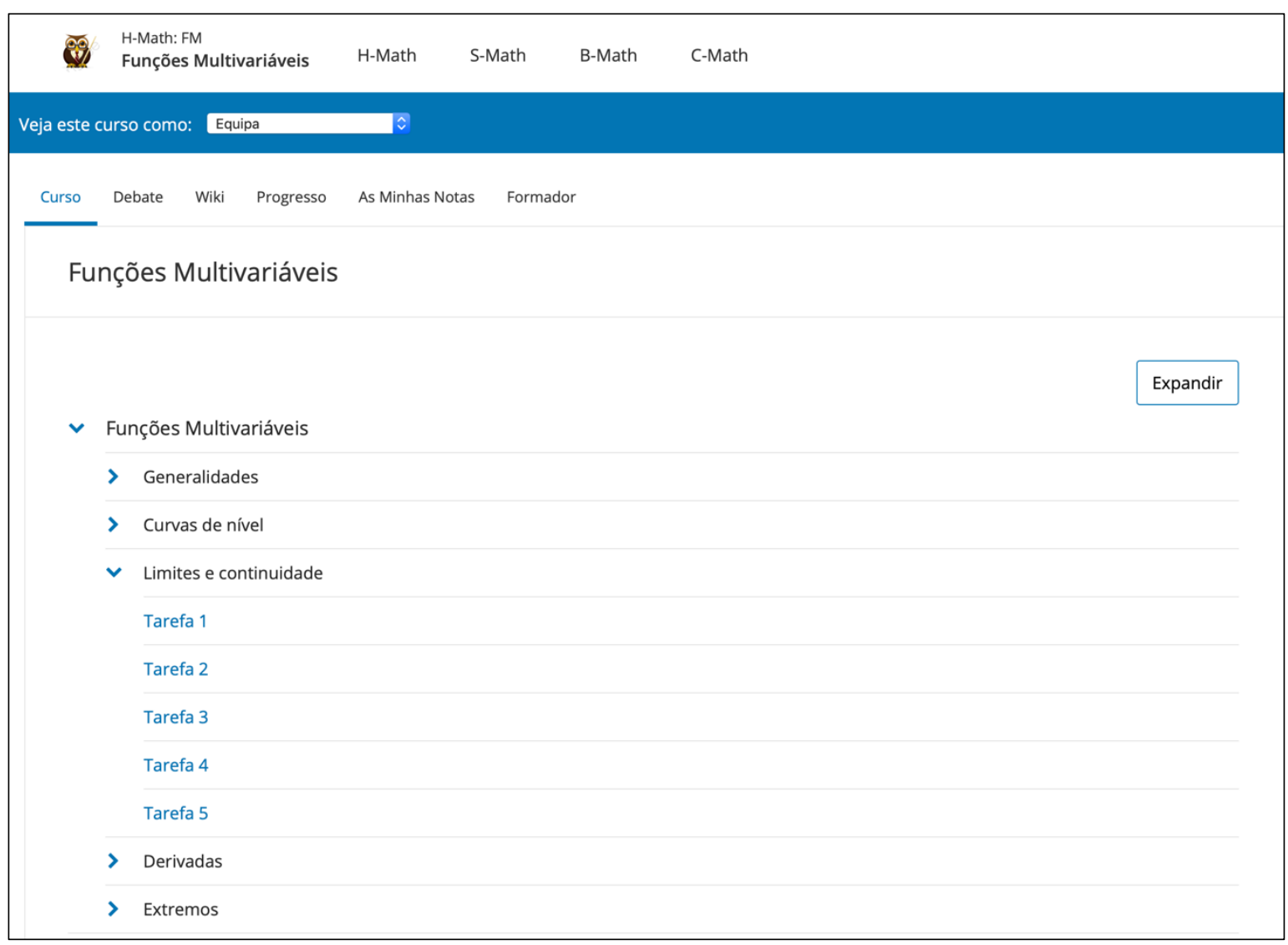

Figure 1. The E-OWL platform interface

More recently, this year, a new platform was developed supported on the Open Edx LMS and named: E-OWL. This platform provides a set of "chapters" that correspond to the themes of a mathematical course. Each chapter is organized with a set of tasks that the student must perform. All tasks give feedback to the student, regardless of whether the answer is correct or not. If it is correct, a positive feedback is given with the resolution, in order the student may verify its resolution. If the answer is not correct the feedback alerts the student that the answer is wrong, as well as indicates suggestions for resolution. Additionally, some tasks present hints that are considered relevant for the execution of them. One of the things to note is that the tasks are arranged in such a way that the theoretical contents appear throughout their completion.

\section{METHOD}

In order to evaluate the platform in an educational context it was used with students enrolled in the 1st year of the Computer Graphics and Multimedia Engineering degree of a higher education institution in the North of Portugal, in the Mathematics course. Students were asked to use the E-OWL platform, in particular, to perform tasks available on it, either in the classroom or in extra-class periods. Moreover, due to the pandemic period related with Covid-19 virus, half of the classes were face-to-face, and the rest were carried out virtually, using the Zoom and Moodle platforms. Subsequently, after the end of the $1^{\text {st }}$ chapter, students were asked to answer a questionnaire about the E-OWL platform, in order to get opinions from the students about the platform they used. The questionnaire consisted of 5 sections. The first section characterising the respondents (age, gender, among others). The following three sections, concerning the characterisation of the E-OWL platform, its classification in an educational context and the use of the platform in teaching/learning processes, were made up of multiple questions using Likert scales. Finally, the last section consisted of an open question, asking students to indicate some advantages and possible disadvantages of using the platform. 


\section{PRESENTATION AND DATA ANALYSIS}

A questionnaire was applied to 35 students aged between $18(17.1 \%)$ and $30(2.9 \%)$, of which $75 \%$ are up to 23 years old. Also, $80 \%$ of the respondents were male and $45.7 \%$ had already attended this course (Figure 2).

\begin{tabular}{|c|c|c|c|}
\hline $\begin{array}{ll}18 & 19\end{array}$ & 21 & 23 & 30 \\
\hline $1^{\circ} \mathrm{Q}$ & $2^{\circ} \mathrm{Q}$ & $3^{\circ} \mathrm{Q}$ & \\
\hline
\end{tabular}

Figure 2. Age of respondents to the questionnaire

Moreover, 34\% had already used online learning platforms, in addition to Moodle (the institutional platform) as one of the following: Virtual School, BitDegree, M@t-Educate-with-success and Udemy. Regarding the E-OWL platform, $51.4 \%$ of the respondents indicated that they accessed up to 2 hours a week and between 2 and 4 hours $48.6 \%$, and before the pandemic, which forced social isolation and confinement at home, $71 \%$ accessed the E-OWL platform only at school.

The remaining (29\%) accessed from the school and the place where they lived at home or in an academic residence. Concerning the difficulty in accessing the E-OWL platform in the process of registering/creating an account and starting to use it, on a scale of 1 (very difficult) to 6 (very easy) 86\% rated between 4 and 6 (Figure 3).

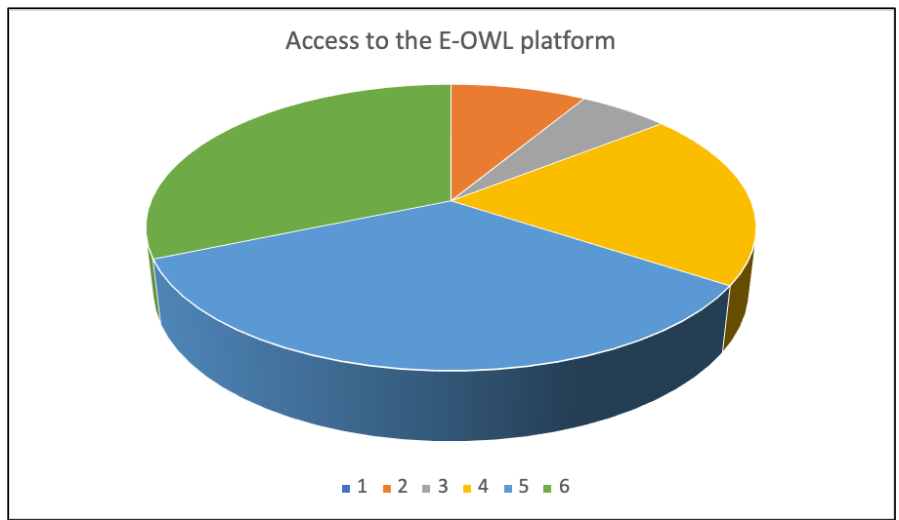

Figure 3. Access quality to the E-OWL platform

Considering the access speed to the platform, on a scale from 1 (very slow) to 6 (very fast), $88 \%$ of the respondents rated it between 4 and 6 (Figure 4).

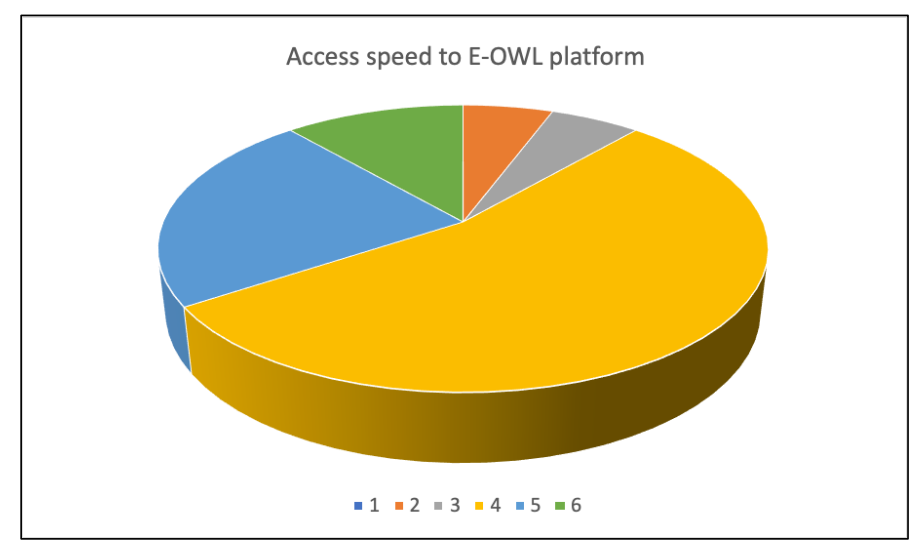

Figure 4. Access speed to E-OWL platform 
As shown in Figure 5, the vast majority of students (more than 90\%) classified the E-OWL platform as reasonable or Good/ Very Good ease of use, accessibility to information, usefulness in supporting autonomous study, usefulness in supporting the course in general, amount of information provided, simple and intuitive organisation, as well as understanding and functioning. It should be noted that more than $40 \%$ considered Good/Very Good the user-friendliness, usefulness in supporting the autonomous study, usefulness in supporting the course in general, amount of information provided, simple and intuitive organization, as well as understanding and functionality. However, 20\%, 17\% and 14\%, respectively, indicated a mediocre diversity of functionalities, usefulness in supporting the updating of relevant information and clarity of language. However, $20 \%, 23 \%$ and $29 \%$, respectively, indicated from Good/Very Good the diversity of functionalities, utility in supporting the updating of relevant information and clarity of language.

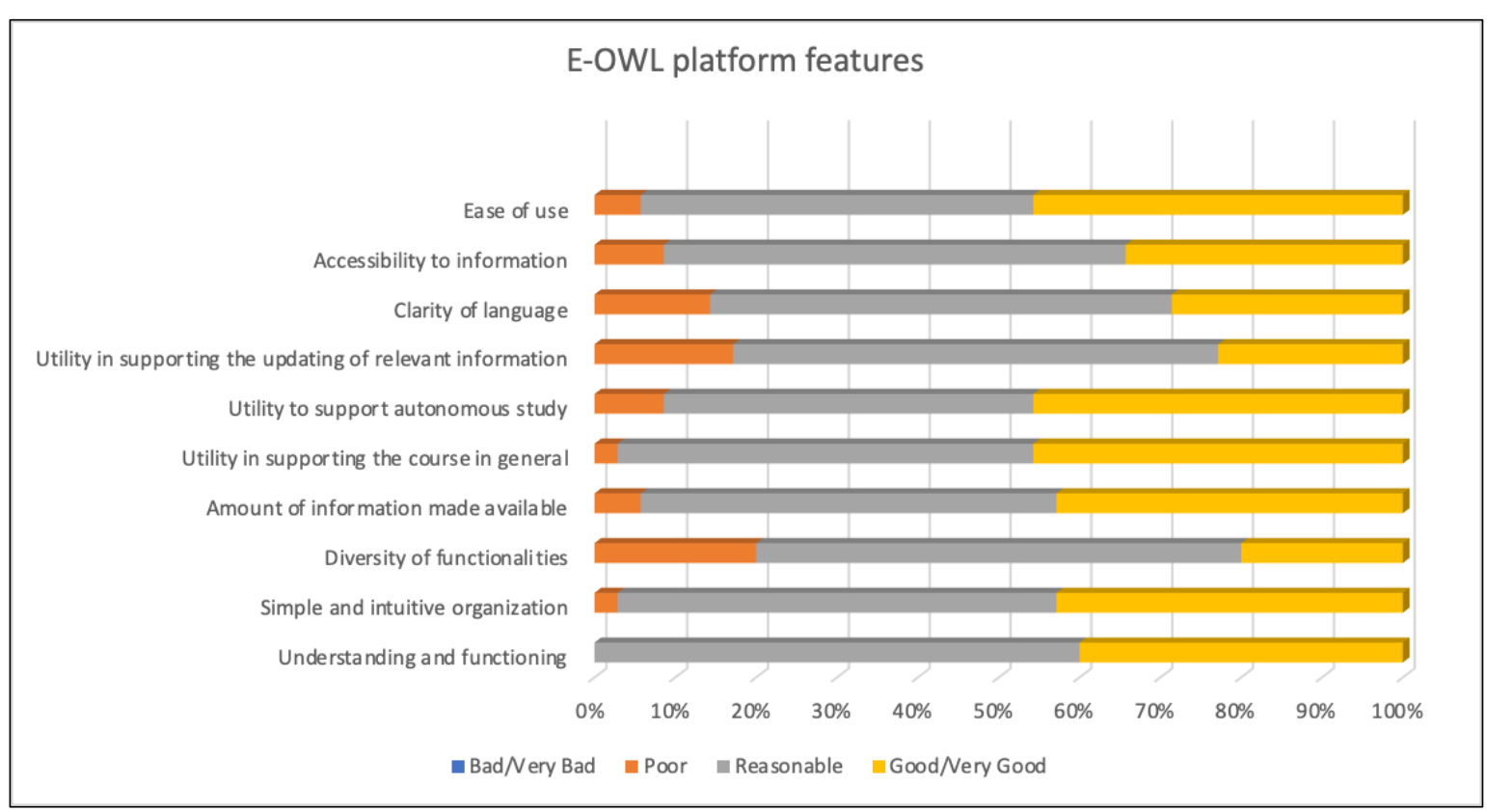

Figure 5. Characterization of some features of the E-OWL platform

Analysing Figure 6, it is observable that almost all students (between 97\% and 100\%) rated as Agree or Strongly Agree this platform allows access to information anytime and anywhere as long as access to the Internet be available, the tasks proposed in the E-OWL platform are relevant, the feedback given to the option indicated helps in understanding the issues involved and the possibility to navigate between "theory" and "practice" is an added value for learning. It is observable that $26 \%$ and $60 \%$ of students, respectively, rated as Strongly Agree and Agree that using the platform has helped to understand the contents. In accordance with the previous classification, (1) $91 \%$ rated as Strongly Agree or Agree with the use of this platform it is possible to better follow the subject in study, as well as indicated as Strongly Agree or Agree (2) 74\% and 89\%, respectively, this platform stimulates continuous study and allows self-regulation of learning. Regarding the statements "The contents of the E-OWL platform are well structured" and "The language of the contents of the E-OWL platform is perceptible and clear" $94 \%$ and $89 \%$ indicated Strongly Agree and Agree, respectively. Also, $20 \%$ of respondents Disagree that this platform respects the learning pace of each. However, $54 \%$ and 26\% indicated Agree and Strongly Agree, respectively. It should be noted that $80 \%$ Disagree or Strongly Disagree that this platform does not facilitate autonomous study. Only 17\% Agreed and 3\% Strongly Agree. Regarding the statement this platform does not oblige to study more, 69\% Disagree or Strongly Disagree, verifying that 26\% and 6\% Strongly Agree and Agree, respectively. Concerning the tasks presented on E-OWL platform not being enough, 60\% Strongly Disagree, despite 9\% Strongly Agree. 


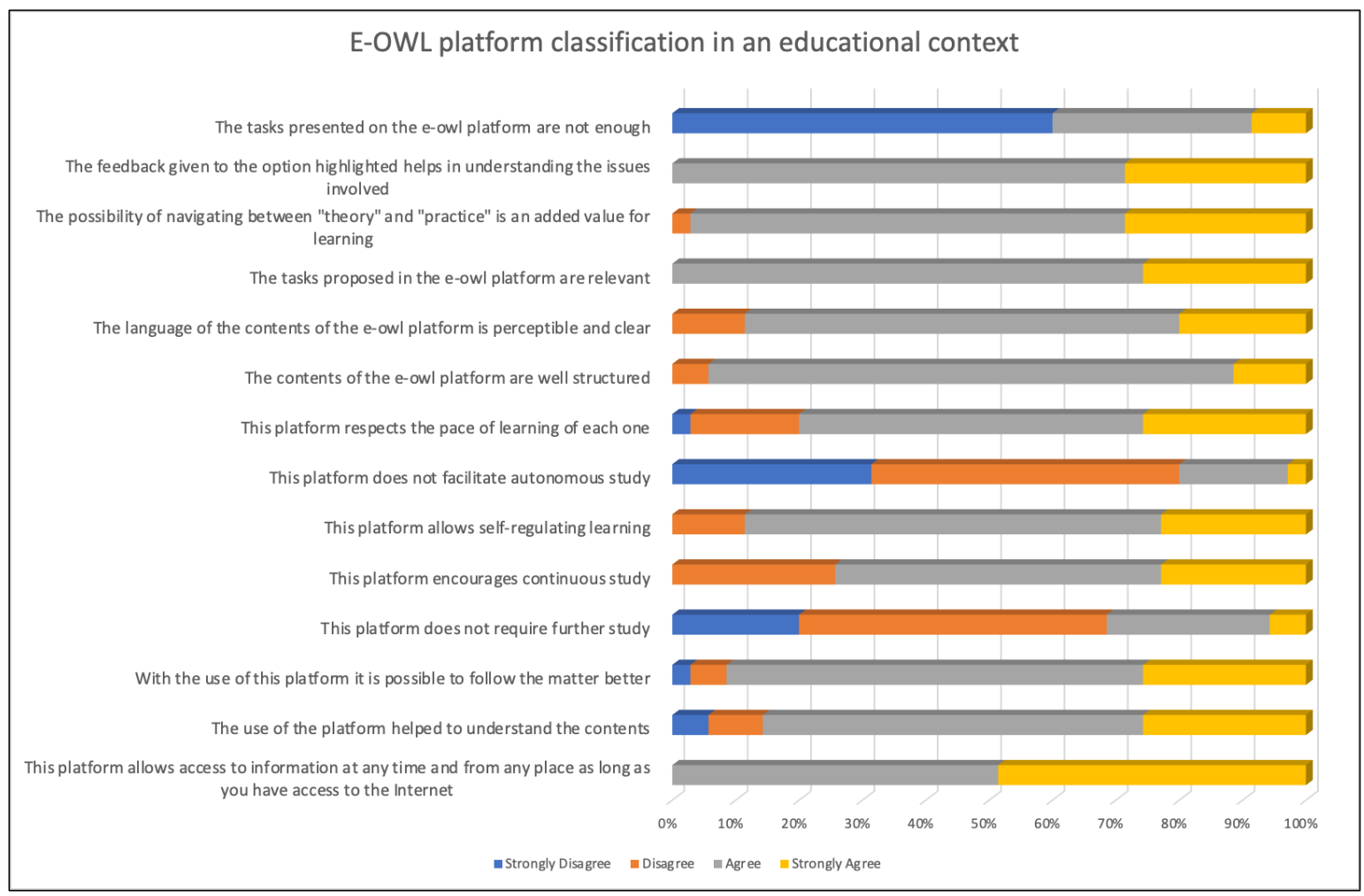

Figure 6. E-OWL platform classification in an educational context

Almost all (94\%) of the surveyed students indicated Agree or Strongly Agree so that the exploration of the tasks proposed in the E-OWL platform facilitates the monitoring of classes and the use of the platform allows the development of mathematical aptitudes. The statement of greatest disagreement $(23 \%)$ was the learning methodology supported in the use of the E-OWL platform promotes autonomous learning, although also $23 \%$ Strongly Agree. Considering the statement "The methodology adopted based on the use of the E-OWL platform facilitates the transfer of acquired knowledge to other tasks (exercises, problems)", 71\% Agree and 17\% Strongly Agree. Summarizing, the students considered that the E-OWL platform supported them in their study and facilitated the construction of knowledge.

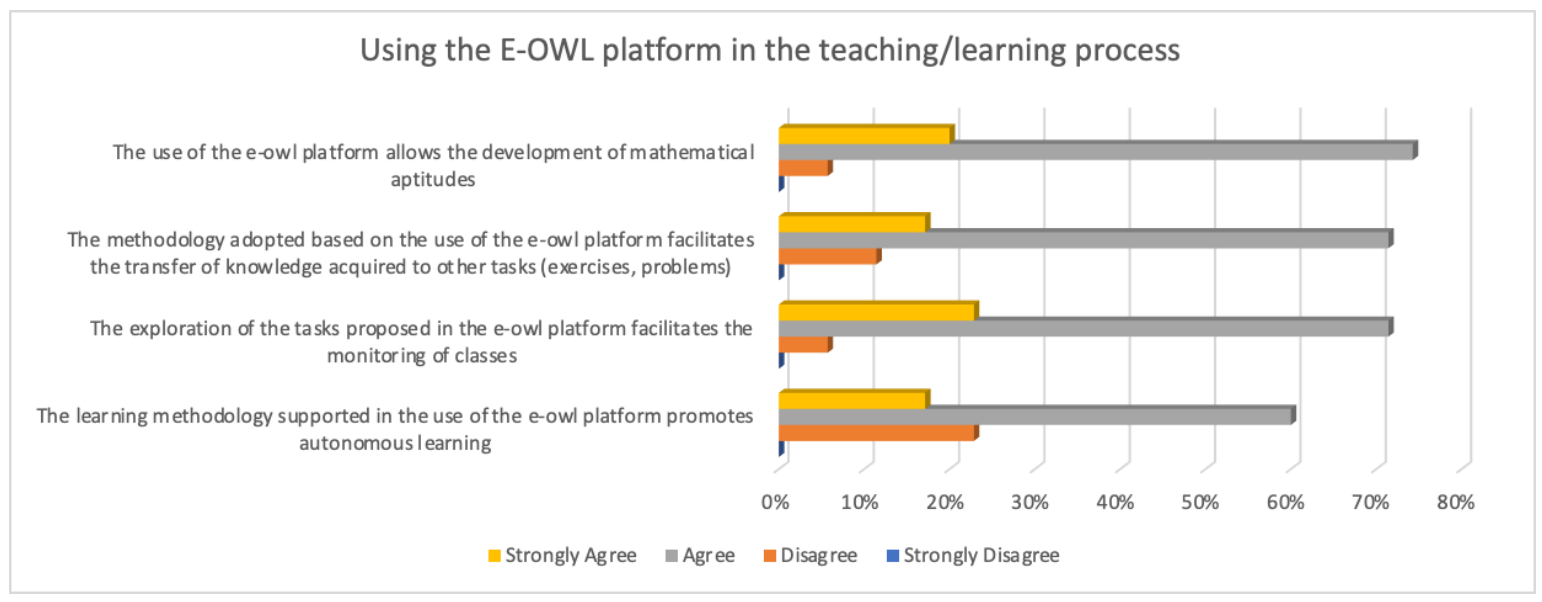

Figure 7. Classification of using E-OWL platform in a teaching/learning process 
On last question, the most frequently mentioned opinion was that the exercises were solved, feedback was given to the student and that they were user-friendly. Some comments in this regard:

- "The access to the platform is easy, it keeps us up to date with the subjects taught in class, it has complementary exercises and their solution to promote a more individualized study. In general, it is a support tool for a continuous student study".

- "It's a good platform for learning. The access to exercises with explanation of the subject helps to understand things better".

- "It explains the essential points to understand the contents, explains the theory while practicing, gives feedback on the exercises, allows more practical learning and therefore closer to an evaluation situation".

The second most quoted opinion is related to self-study/self-learning, as evidenced by the following comments:

- "Easy accessibility, help in self-study, help in understanding the subject and gives important examples of certain points of the subject".

- "Using the platform allows us to study a little more independently. It allows us to apply theory to the resolution of exercises, and at the same time the feedback that is given at the end of the answer is very important, because it helps us to understand better the theory that we may not know so well yet".

- "This platform allows self-learning and the discovery of new concepts".

Lastly, as a whole, the students considered that this platform was a strong support to the classes at distance, providing the contents in a more appealing and interactive way.

\section{CONCLUSION}

According to the diagnostic analysis carried out, the E-OWL platform is easy to use, useful in supporting the courses, as well as in supporting autonomous study, stimulating continuous study and allowing self-regulation of learning and respecting the learning rhythm of each student, both during the classes in person and during the period when all the classes were online. It should be noted that the students considered that the feedback given to the option indicated helps in understanding the issues involved, and almost all the students agreed that the possibility of navigating between "theory" and "practice" constitutes an added value for learning, and with the use of this platform it is possible to better follow the course contents. In this sense it can be said that the platform facilitates the construction of knowledge and it is an interesting support in the learning process. We believe that in a current context, given the young students who are very familiar with the technologies, investment should continue to be made in the creation and evolution of interactive online platforms for teaching and learning in order to meet students' needs and interests.

This article is a first study on the E-OWL platform. Further studies may be carried out at a later stage, including a comparison of the differentiating features of this platform and others that already exist.

\section{REFERENCES}

Al-Rahmi, W., Alias, N., Othman, M., Alzahrani, A., Alfarraj, O., Saged, A. \& Rahman, N., 2018. Use of E-Learning by University Students in Malaysian Higher Educational Institutions: A Case in Universiti Teknologi Malaysia. IEEE Access, Vol. 6, pp. 14268-14276.

Al-Samarraie, H., Teng, B., Alzahrani,A. \& Alalwan, N., 2018. E-learning continuance satisfaction in higher education: a unified perspective from instructors and students. Studies in Higher Education, Vol 43, No 11, pp 2003-2019.

Antunes, C. (2010). Utilizando a tecnologia a seu favor. $17^{a}$ Ed. Petrópolis, RJ: Vozes.

Carabetta Júnior, V., 2010. Rever, pensar e (re)significar: a importância da reflexão sobre a prática na profissão docente. Revista Brasileira de Educação Médica, Vol. 34 N 4, pp 580-586.

Bertoncello, L., 2010. A utilização das TIC e sua contribuição na educação superior: uma visão a partir do discurso docente da área de letras. Disponível em: https://www.recursos.portaleducoas.org/publicaciones/utiliza-o-das-tic-e-suacontribui-o-na-educa-o-superior-uma-vis-o-partir-do-discurso?audience=3\&area=\&country= 
Daniela, L., Strods, R., Daiga, K., 2019. Technology-enhanced learning (tel) in higher education: Where are we now? In Lytras, D., Miltiadis, Daniela, L. \& Visvizi, A.(orgs); 2019. Knowledge-intensive economies and opportunities for social, organizational, and technological growth, Igi Globa Publisher of timely Knowledge, pp. 12-24

Freire, P.; Shor, I. A, 1987. Pedagogy of Liberation: Dialogues for Transforming Education. Boston: Bergin and Garvey.

Kirkwood, L. Price, 2014. Technology-enhanced learning and teaching in higher education: What is 'enhanced' and how do we know? A critical literature reviews

Learning, Media and Technology, Vol. 39, pp. 6-36

Lobo, A., Maia, L., 2015. O uso das TICs como ferramenta de ensino-aprendizagem no Ensino Superior. Caderno de geografia, Vol. 25, N44, pp 16-26

Moraes, C.R., Varela, S., 2007. A motivação do aluno durante o processo de ensino-aprendizagem. Revista eletrônica de educação. Vol.1, No 1, pp 1-15.

Moran, J. M.; Masetto, M. T.; Behrens, M. A., 2007. Novas tecnologias e mediações pedagógicas. 13. ed. São Paulo: Papirus.

Martinsi, M.C., 2008. Situando o uso da mídia em contextos educacionais. Portal do MEC.

Nortvig, A.; Petersen, A.; Balle, S., 2018. A Literature Review of the Factors Influencing E-Learning and Blended Learning in Relation to Learning Outcome, Student Satisfaction and Engagement._Electronic Journal of e-Learning, Vol 16, $\mathrm{N}^{\circ}$ 1, pp 46-55.

Paechter, M., Maier, B. \& Macher, D., 2010. Expectativas e experiências dos alunos em e-learning: sua relação com as conquistas da aprendizagem e a satisfação com o curso. Computadores e Educação, Vol. 54, pp 222-229.

Pereira, B.T.; Freitas, M.C, 2010. O uso das tecnologias da informação e comunicação na prática pedagógica da escola. Disponível em: http://www.diaadiaeducacao.pr.gov.br/portals/pde/arquivos/1381-8.pdf

Ricoy, M. \& Couto, M., 2014. As boas práticas com TIC e a utilidade atribuída pelos alunos recém-integrados na universidade. Educação e Pesquisa, Vol. 40, № 4, pp 897-912.

Valente, J., 2002. Uso da internet em sala de aula. Educar em Revista, Curitiba, № 19, pp 131-146.

Valente, J. A., 2003. Curso de especialização em desenvolvimento de projetos pedagógicos com o uso das novas tecnologias: Descrição e fundamentos. In: Valente, J., Prado, M. \& Almeida, M. (orgs), 2003. Educação a Distância Via Internet. São Paulo: Avercamp. pp 23-55. 